\title{
The Impact of Principal Emotional Intelligence on Teacher Perceptions of School Climate
}

\author{
Ashley Allred ${ }^{1}$, Myron B. Labat ${ }^{2}$, Daniel W. Eadens ${ }^{3}$, Cherie A. Labat ${ }^{2} \&$ Danielle M. Eadens $^{4}$ \\ ${ }^{1}$ Jackson County School District, Vancleve, Mississippi, USA \\ ${ }^{2}$ Department of Educational Leadership, University of Southern Mississippi, Hattiesburg, Mississippi, USA \\ ${ }^{3}$ Department of Educational Leadership, Northern Arizona University, Flagstaff, Arizona, USA \\ ${ }^{4}$ Department of Educational Specialties, Northern Arizona University, Flagstaff, Arizona, USA \\ Correspondence: Myron B. Labat, Department of Educational Leadership, University of Southern Mississippi, \\ Hattiesburg, Mississippi, USA Tel: 228-323-4980.
}

Received: April 25, 2016

doi:10.5430/irhe.v1n2p127
Accepted: May 10, 2016

Online Published: July 20, 2016

URL: http://dx.doi.org/10.5430/irhe.v1n2p127

\begin{abstract}
The purpose of this research study was to analyze the impact of principals' emotional intelligence on the perceptions that teachers have of their school's climate. The Organizational Health Inventory for Middle Schools (OHI-M) served as the assessment for teachers' perceptions of the school climate, or the overall health of the organization. Principals' emotional intelligence competencies were assessed using the Mayer Salovey-Caruso Emotional Intelligence Test version 2, hereinafter referred to as the MSCEIT. Participants of the study included 22 middle school principals in Mississippi. There were an average of 45 teachers employed at each middle school. A Pearson product-moment correlation analysis was conducted in order to assess the relationship between principals' emotional intelligence competencies and teachers' perceptions of the schools' climate, as evidenced by responses to the OHI-M. A statistically significant positive relationship was found between the principals' ability to understand emotions and the teachers' perceptions of school climate.
\end{abstract}

Keywords: emotional intelligence, school climate, school culture, school leadership, leadership, transformational leadership

\section{Introduction}

In the current educational climate of high accountability and high expectations, effective leadership is paramount. Schools are in need of dynamic leaders who can create and foster a following, loyalty to a vision, and have laser like focus on achievement. As educators implement Common Core State Standards it is more important than ever that leaders are able to lead, communicate, and pursue a school's vision and mission effectively. Extensive research exists on the characteristics of great leaders, as well as many leadership techniques (Blumberg \& Greenfield, 1986; Bohlman \& Deal, 2002; Burns, 1978; DuFour \& Marzano, 2011; Manasse, 1986; Marzano, Waters, \& McNulty, 2005). Goleman, Boyatzis, and McKee (2002) assert that the fundamental task of leaders is to prime good feelings in those that they lead, making the primal job of leadership emotional at its root.

At no other time in the PK12 education spectrum are students' needs so diverse and broad than that of the middle school years. The physical, social, and emotional development of middle school students often produces an environment of inconsistency and unpredictability. Newlin (2009) described the importance of providing encouragement, support, and collaborative coaching to middle school teachers. Styron's article, "Key Characteristics of Middle School Performance" (2008), described such healthy relationships among the staff as a way to create a healthy school climate. Great leadership cultivates a powerful climate. According to Hoy and Sabo (1998), a healthy climate is a critical component of effective middle schools.

\section{Review of Literature}

School climate is a crucial element in student achievement (Cohen et al., 2009; DuFour \& Marzano, 2011; Hoy \& Sabo, 1998; Styron, 2008). Leaders with high emotional intelligence (EQ) may have a prodigious impact on a school's climate. They can create a healthy environment where employee emotions are well managed and teachers 
are able to perform effectively, thereby safeguarding student achievement (Blumberg \& Greenfield, 1986; Goleman, 2006; Goleman et al., 2002; Mayer, Roberts, \& Barsade, 2008; Moore, 2009). Unfortunately, a thorough review of the literature relative to EQ and its implications for middle school principals, and specifically how teachers perceive the resulting climate, is very limited.

The volume of theory and research concerning leadership over many decades is a testimony to its prominence and individuals' efforts to understand its effect in their world (Meindl, Ehrlich, \& Dukerich, 1985). Stogdill (1974) noted, "There are almost as many definitions of leadership as there are persons who have attempted to define the concept" (p. 259). Lewin and Lippit's 1938 seminal research on small group performance compared autocratic to democratic leadership, a study in the function of leadership during the command-control days of industry (Kaiser, McGinnis, \& Overfield, 2012). Researchers at Ohio State University compared initiating structure and consideration in developing their two-factor paradigm of leader behavior. They took a more engaging, humanistic approach, according to (Kaiser et al., 2012).

Burns (1978) and Bass (1985) introduced the modern world to a new wave of leadership by comparing transactional and transformational styles of leadership. The core assumption is that leaders affect organizational performance by inspiring, supporting, and motivating followers through influence (Bass, 1985; Burns, 1978; Hersey \& Blanchard, 1988; Kaiser et al., 2012).

\section{Methodology}

The purpose of this study was to reveal branches of middle school principals' emotional intelligence (EQ) that may have an impact on teachers' perceptions of school climate. Research has indicated that individuals with higher levels of Emotional Intelligence have a positive impact on the organizations that they lead (Mayer et al., 2000; Goleman et al., 2002). The research design for this study was a quantitative, correlational study using data obtained from two different survey instruments. The principals participating in this study were administered the Mayer Salovey-Caruso Emotional Intelligence Test v.2 (MSCEIT) online. The teachers' perceptions of school climate data were collected using the Organizational Health Inventory for Middle Schools (OHI-M) by Hoy and Tarter (1997).

\subsection{Participants}

The target population for this study consisted of middle school principals and teachers in 35 public schools districts located in the state of Mississippi. Sixty-six principals were invited to participate in the study with 22 of the 66 agreeing to complete the questionnaire representing a response rate of $33 \%$. Five hundred and fifty teachers were invited to participate in the study. Of the 550 surveys disbursed, 314 of them were returned completed representing a teacher response rate of $55.6 \%$. Of the 22 principals participating in the survey, $11(50 \%)$ were females, $9(40.9 \%)$ were males, and 2 principals chose not to report their gender. The ages of the participating principals ranged from 35 to 65 years of age, with four principals not reporting their age. The median and mean age for the principals was 48 . Eight principals (36.4\%) reported being Black/African-American, while 11 (50\%) reported being White. Three principals chose not to report their ethnicity. Demographic information was not collected from the participating teachers.

\section{Results}

The primary purpose of this study was to examine the relationship between principal Emotional Intelligence (EQ) and teachers' perceptions of school climate. The study also sought to analyze which, if any, branch of a middle school principal's emotional intelligence had a stronger statistical impact on the teachers' perceptions of the school's climate. The 22 participants in the sample had a mean total EQ score of 82 with a standard deviation of 24 . According to Mayer et al. (2002), the MSCEIT has a mean of 100 and a standard deviation of 15 . The sample mean is greater than one standard deviation below the mean, while the sample standard deviation is slightly higher, showing greater variance in the sample scores. The median score, 87 , fell within the average range. Table 1 provides the branch means of the sample, as well as the standard deviation and range of scores. 
Table 1. MSCEIT branch descriptives of sample

\begin{tabular}{lccc}
\hline \multicolumn{1}{c}{ EQ Branch } & Mean & Standard Deviation & Range of Scores \\
\hline Identify (B1) & 88 & 18 & $56-120$ \\
Use (B2) & 94 & 23 & $49-138$ \\
Understand (B3) & 86 & 14 & $51-107$ \\
M a n a g e & 96 & 21 & $58-127$ \\
(B4) & & & \\
\hline
\end{tabular}

\section{School Climate}

The instrument used to assess the teachers' perceptions of the school climate was the Organizational Health Inventory- Middle level (OHI-M). Upon the completion of the MSCEIT by each participating principal, teachers at the participating schools were provided with the OHI-M and invited to participate. The sample in this study yielded a mean of 524 and a standard deviation of 68 . While the sample mean is within normal limits, it should be noted that $59 \%$ of the participating schools scored at or above the Above Average category, creating a positively skewed distribution of the data. Table 2 presents the frequencies of the OHI-M category score results, indicating a positive skew in the sample data.

Table 2. Frequencies of the OHI-M categories

\begin{tabular}{lcc}
\hline \multicolumn{1}{c}{ OHI-M categories } & Frequency & Percent \\
\hline Very High (Above 600) & 4 & 18.2 \\
High (551-600) & 4 & 18.2 \\
Above Average (525-550) & 5 & 22.7 \\
Slightly Above Average (511-524) & 2 & 9.1 \\
Slightly Below Average (476-489) & 2 & 9.1 \\
Below Average (450-475) & 2 & 9.1 \\
Low (400-449) & 2 & 9.1 \\
Very Low (Below 400) & 1 & 4.5 \\
\hline
\end{tabular}

$N=22$

The OHI-M is comprised of six subtests, which include institutional integrity, collegial leadership, principal influence, resource support, teacher affiliation, and academic emphasis. Institutional integrity is a school's ability to cope with its environment while maintaining educational integrity, as well as protecting teachers from unreasonable community and parental demands. Collegial leadership is the second subtest of the OHI-M. This subtest measures principal behavior that is friendly, supportive, open, and equitable. This subtest returned the largest standard deviation of all six subtests. The third subtest of the OHI-M is principal influence. This subtest measures the principal's ability to influence the actions of others. The fourth subtest of the OHI-M measured the extent to which 
classroom supplies and instructional materials are readily available. Teacher affiliation is the fifth subtest of the OHI-M, and it measures the sense of friendliness and affiliation within a school. This subset asks the question(s) $D o$ teachers feel good about each other, their job, and their students? The final subtest of this instrument is the academic emphasis subtest. Academic emphasis is the school's drive for success in academic excellence. A high score in academic emphasis is reflective of a school with high but achievable goals being set for students, the learning environment is orderly and serious, teachers believe in their students, and others respect students for working hard to perform well academically. Table 3 lists descriptive statisticts for each subtest of the OHI-M.

Table 3. OHI-M subtest descriptive statistics of the sample

\begin{tabular}{lccc}
\hline \multicolumn{1}{c}{ OHI-M Subtests } & Mean & Standard & Range of Scores \\
& & Deviation & \\
\hline Institutional Integrity & 592 & 80 & $392-751$ \\
Collegial Leadership & 532 & 125 & $265-732$ \\
Principal Influence & 529 & 90 & $298-671$ \\
Resource Support & 520 & 81 & $400-697$ \\
Teacher Affiliation & 366 & 72 & $415-765$ \\
Academic Emphasis & 602 & 97 & $413-765$ \\
\hline
\end{tabular}

The subtest scores yielded by the sample were within the normal range with the exception of two: teacher affiliation and academic emphasis. The normative mean for this assessment is 500. A teacher affiliation score of 366 is 2.6 standard deviations below the mean and in the Very Low category for school climate. In contrast, the academic emphasis branch mean is 602 , which is slightly above one standard deviation beyond the mean. Moreover, a standard deviation of 125 in the collegial leadership category indicates a very large variance in teachers' perceptions of the principals.

\section{Discussion}

Hoy and Sabo (1998) described a healthy school climate as a "critical" component of a middle school. Lees and Barnard (1999) provided evidence that certain emotional intelligence competencies ultimately lead to greater job satisfaction and higher student achievement. "When people feel good, they work at their best" (p. 14). The Pearson $r$ scores for each correlation represented the existence of positive relationships; however, the results were all found to be statistically insignificant, with the exception of one relationship.

The Pearson $r$ correlation between the principals' ability to understand emotions and the teachers' perception of school climate revealed a moderate, positive correlation with statistical significance.

While this aspect of emotional intelligence is not suggested to cause an increase in school climate scores, it does indicate that a positive relationship exists between the two variables. As principals' ability to understand the emotions of their employees increases, the teachers' perceptions of the school climate should increase as well. Upon analyzing the statistically significant relationship between the Understanding branch of EQ and school climate, one can determine that a positive relationship exists. With a correlation of $r=.422$ at the .05 level, it is evident that increases in one variable is associated with increases in the other variable. Additionally, the low standard deviation of the sample in this area of EQ exhibits the strength of this branch's ability to influence a school's climate score. It is likely that statistical significance among all levels of the independent variable may have been evident if the sample sizes were larger. Given the small size of the sample, the statistical significance of the understanding branch of emotional intelligence solidifies the strong relationship that exists between the two variables.

While positive correlations were found in the study, the lack of statistical significance limits the generalizability of 
the study.

Research by Condren (2002) and Henry and Hope (2013) revealed similar findings. Condren's sample size of 32 returned positive, statistically insignificant results between principals' EQ and leadership effectiveness. Henry and Hope (2013) also found statistically insignificant results in the correlation of Adequate Yearly Progress (AYP) status and principals' EQ. Due to the research suggesting strong correlations, there is a need to further analyze emotional intelligence and investigate its relationship between leadership and school climate. Goleman's research on leaders' EQ combined with research on teacher morale (Whitaker et al., 2009) and school climate (Cohen, McCabe, Michelli, \& Pickeral, 2009) point to strong evidence that an emotionally intelligent leader does have a profound impact on his or her followers. Goleman et al. (2002) contends that at its root, the primal job of leadership is emotional. It is to prime good feelings in followers. He further asserts that leadership is crucial during times of grave crisis, positing that such times lead all followers to turn their eyes to the leader for emotional guidance. Leaders have a way of interpreting, making sense, and not reacting emotionally to given situations (Goleman et al., 2002). When individuals are asked to describe great leaders, they often describe strategies, leadership styles, vision, or ideas. But, in reality, Goleman et al. (2002) imagined that great leaders work through emotions; "Great leaders move us. They ignite our passion and inspire the best in us" (p. 3).

\section{Conclusion}

Teachers' perceptions of school climate are largely influenced by their attitudes. If principals possess the ability to change, transition, or affect the attitude of a teacher by understanding their emotions, the climate of the school would be impacted. Administrators could benefit from specific training through principal preparation programs that focus on personal EQ and its impact on teachers. In A Place Called School, Goodlad (1984) referred to schools with low teacher and student satisfaction as 'unhealthy' organisms not able to take on the task of reform. Until school environments are healthier for both students and teachers, educators cannot expect results from reform efforts (Gordon, 2013). Additionally, if researchers are able to determine that emotional intelligence is related to school climate and that a positive school climate is correlated with student achievement, this information could prove valuable for school districts seeking to hire leaders who can significantly impact school climate and thus student success.

\section{References}

Bass, B. M. (1985). Leadership and performance beyond expectation. New York, NY: Free Press.

Blumberg, A., \& Greenfield, W. (1986). The effective principal: Perspectives on school leadership (2nd ed.) Boston, MA: Allyn \& Bacon.

Burns, J. M. (1978). Leadership. New York, NY: Harper and Rowe.

Cohen, J., McCabe, E., Michelli, N., \& Pickeral, T. (2009). School climate: Research, policy. Teachers College Record, 111(1), 180-213. $\quad$ Retrieved from http://www.schoolclimate.org/climate/documents/policy/School-Climate-Paper-TC-Record.pdf

Condren, T. (2002). The relationship between principals' emotional intelligence and leadership effectiveness. Retrieved from http://www.leadershipchallenge.com/Research-section-Others-Research-Detail/abstract-condren---the-relationsh ip-between-principals-emotional-intelligence-and-leadership-effectiveness.aspx

Dufour, R., \& Marzano, R. (2011) Leaders of learning: How district, school, and classroom leaders improve student achievement. Bloomington, IN; Solution Tree Press.

Goleman, D. (2006). The socially intelligent leader. Educational Leadership, 76-81.

Goleman, D., Boyatzis, R., \& McKee, A. (2002). Primal leadership: Realizing the power of emotional intelligence. Boston, MA: Harvard Business School Publishing.

Goodlad, J. I. (1984). A place called school: Prospects for the future. New York, NY: McGraw-Hill.

Gordon, G. (2013). School leadership linked to engagement and student achievement. Gallup Press.

Henry, E., \& Hope, W. (2013). Principals Emotional Intelligence and its Impact on Adequate Yearly Progress. Journal of Educational Research in Action. Retrieved from http://www.lindenwood.edu/ela/issue01/henryHope.html

Hersey, P., \& Blanchard, K. (1988). Management of organizational behavior (3rd ed.). Englewood Cliffs, NJ: Prentice-Hall. 
Hoy, W. K., \& Sabo, D. (1998). Quality middle schools: Open and healthy. Thousand Oaks, CA: Corwin Press.

Hoy, W. K., \& Tarter, C. J. (1997). The road to open and healthy schools: A handbook for change, Elementary Edition. Thousand Oaks, CA: Corwin Press.

Kaiser, R. B., McGinnis, J., \& Overfield, D. V. (2012). The how and the what of leadership. Consulting Psychology Journal: Practice and Research, 64(2), 119. http://dx.doi.org/10.1037/a0029331

Mayer, J. D., Roberts, R. D., \& Barsade, S.G. (2008). Human Abilities: Emotional Intelligence. Annual Review of Psychology, 59, 507-536. http://dx.doi.org/10.1146/annurev.psych.59.103006.093646

Meindl, J. R., Ehrlich, S. B., \& Dukerich, J. M. (1985). The romance of leadership. Administrative Science Quarterly, 30, 78-102. http://dx.doi.org/10.2307/2392813

Moore, D. B. (2009). Emotional Intelligence for school administrators: A priority for school reform? American Secondary Education, 20-28.

Stogdill, R. M., (1974). Handbook of leadership, New York, NY: The Free Press.

Styron, J. R. (2008). Key characteristics of middle school performance. Middle Level Education Online, 31(5), 1-17. Inhttp://dx.doi.org/10.1080/19404476.2008.11462048

Whitaker, T., Whitaker, B., \& Lumpa, D. (2009). Motivating \& inspiring teachers: The educational leader's guide for building staff morale. Larchmont, NY: Eye on Education, Inc.. 